\title{
Mirror Syndrome - A Rare Case
}

\author{
Sukesh Kathpalia* \\ Commandant, Military Hospital, Allahabad, India
}

Received: January 19, 2018; Published: January 24, 2018

*Corresponding author: Sukesh Kathpalia, Commandant, Military Hospital, Allahabad, India, Email: kathpaliasukesh@gmail.com

\begin{abstract}
Mirror syndrome is a maternal condition which develops as a result of fetal condition, the main feature being edema; both mother and fetus appear as mirror image of each other. Initially it was described as maternal edema in response to fetal edema due to Rhesus isoimmunisation. Subsequently it has been found in fetal hydrops due to both immune and non immune causes. The maternal condition is likely to improve after fetal treatment, demise or delivery. One case of mirror syndrome due to non immune hydrops is being presented who recovered completely after delivery. The cause of this syndrome is still not understood probably it is placental hypertrophy resulting in high hCG levels. Both mother and fetus are at risk in this condition.
\end{abstract}

Keywords: Ballantyne syndrome; Fetal Hydrops, Preeclamsia

\section{Introduction}

Mirror syndrome is a maternal condition which develops as a result of fetal condition, the main feature being maternal and fetal edema. Both appear as mirror image of each other hence named so. The term 'Mirror Syndrome' was first introduced by O'Driscoll who found this condition in cases of fetal hydrops due to $\mathrm{Rh}$ Isoimmunisation [1]. This clinical condition was discovered as early as 1892 by John W Ballantyne who found and explained the association of maternal edema in pregnancy with fetal and placental hydrops due to rhesus is immunization [2]. Subsequently this rare condition has been found in cases of fetal hydrops due to other varied causes. One such uncommon case of 'Mirror Syndrome' due to non immune hydrops is being presented.

\section{Case Report}

27 years old gravida 2 para 1 was a booked case at a peripheral outpatient clinic. She was on regular follow up there when the medical attendant detected that patient had gained excessive weight and was hypertensive hence she was referred to this hospital. At that time she was 29 weeks pregnant and did not have any complaint except swelling feet of insidious onset of two weeks duration. Her past medical and surgical history was unremarkable. She had one normal delivery three years back. Premonitory symptoms or breathing difficulty were not present. Her weight was $87 \mathrm{~kg}$ (pre pregnancy her weight was $63 \mathrm{Kg}$ ), BP 170/110 $\mathrm{mm}$ of $\mathrm{Hg}$, her BP was recorded as normal on the previous visit which was four weeks prior, and there was mild pallor. She had excessive pedal edema up to mid thighs and abdominal wall. There was mild pallor otherwise general and systemic examination was essentially normal. Obstetrical examination showed fundal height of 34 weeks (at gestation of 29 weeks) with abdominal wall edema. Fetal parts were felt but with difficulty due to excessive abdominal wall swelling. Fetal heart rate was normal. Her blood group was A $\mathrm{Rh}$ positive. She was admitted to the obstetrical ward for detailed investigations, rest and close monitoring. She was started on Labetalol. Her Hb was 8.3 gm\%, with normal leukocyte count but platelets were low $(77,000 / \mathrm{ml})$, prothrombin time and INR were normal. Blood sugar, kidney function tests and liver function tests, HIV and other viral markers were normal.

Ultrasound done that day revealed fetal ascites, bilateral pleural effusion and skin edema. Head circumference and femur length were corresponding to 25 weeks gestation but abdominal circumference was equal to 32 weeks size. Heart, spine and kidneys were normal, and amniotic fluid was normal. Placenta was located fundo posteriorly. The cause of fetal hydrops was not clearly understood, $\mathrm{Rh}$ isoimmunisation and $\mathrm{ABO}$ incompatibility were ruled out. TORCH test and mother's Hb electrophoresis were normal. Facilities for amniocentesis, karyotype, and fetal echocardiography were not available. Parents were counseled about poor fetal prognosis and risk to mother, they agreed for termination. Since Bishop's score was poor cervical ripening was initiated. With priming doses only she went into labour and developed manifestations of revealed type abruptio placenta during late first stage of labour, lost about $300 \mathrm{ml}$ of fresh blood. Augmentation after ARM was done and she progressed normally and delivered a male still born baby weighing $1.5 \mathrm{~kg}$, baby had massive distention of abdomen due to ascites (Figure 1). Placenta was markedly enlarged and weighed 
1.2 Kg (Figure 2). She improved after delivery; her blood pressure became normal without antihypertensive after eight days. She was reviewed after two weeks when her swelling had disappeared completely. Postmortem examination of baby was not agreed to and HPE of placenta was unremarkable

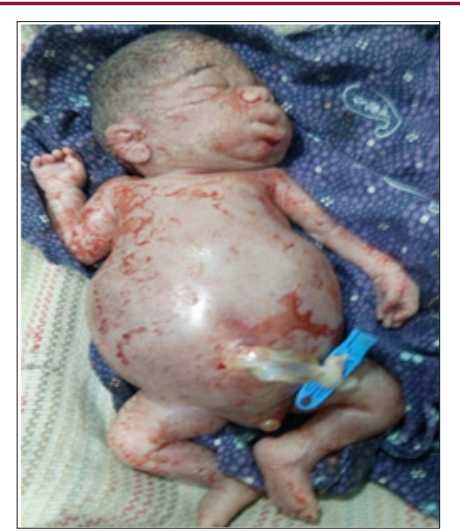

Figure 1: Fetal hydrops (Abdominal distension due to Ascites).

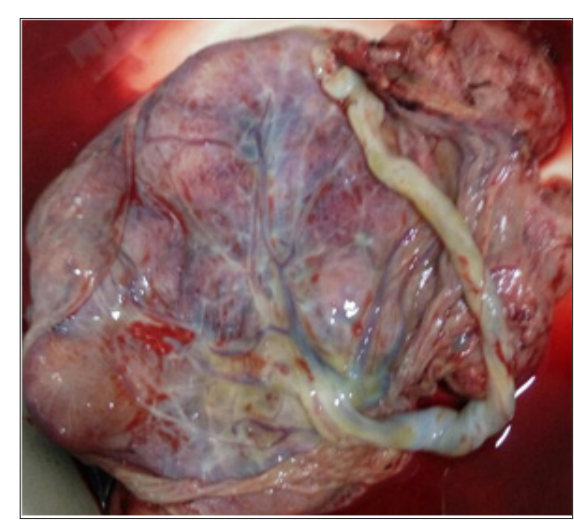

Figure 2: Hydropic and enlarged placenta weighing 1.2 Kg (Baby's weight $1.5 \mathrm{Kg}$ ).

\section{Discussion}

Mirror syndrome, an exceptionally rare condition [3]. Is described as the fetal hydrops and maternal edema along with excessive weight gain as found in preeclampsia [4]. This condition is different from preeclampsia as it is associated with hemodilution [5]. Where as preeclampsia is linked with hem concentration. Eclamptic fits are unknown in mirror syndrome. Clinical entity of Mirror syndrome is known for more than 100 years yet the causation is not clearly understood [6]. Only after development of ultrasound, the diagnosis of this condition has been possible. Basically it is the fetal hydrops which is the initiating event in causation and manifestation of mirror syndrome. The condition is also called triple edema [7]. as it affects fetus, placenta and mother; all having fluid accumulation. The name "Mirror Syndrome" refers to the similarity between maternal edema and fetal hydrops. Fetal hydrops may be due to immunological or non immunological causes [3]. though when it was first described it was due to Rhesus isoimmunisation. Many non immunological causes have been described such as fetal cardiac defects, arrhythmias, aneurysm of vein of Galen, sacrococcygeal teratoma, placental chorioangioma, infection with human parvovirus, Coxsackie B and cytomegalovirus. Mirror syndrome has been reported in multiple pregnancies due to supraventricular tachycardia in one fetus, TTTS (Twin to Twin Transfusion Syndrome) in a dichorionic triplet pregnancy, and unknown etiology in one fetus in a dichorionic pregnancy [8]. Congenital mesoblastic nephroma (CMN), an extremely rare cause of mirror syndrome has been reported by Takahashi [9]. It is the fetal hydrops irrespective of its etiology which is responsible for maternal condition [7].

Mirror syndrome is associated with a marked increase in fetal mortality and maternal morbidity. Treatment is usually in the interest of the mother unless the fetus has some correctable condition while in utero. Maternal symptoms improve dramatically after delivery or fetal death $[10,11]$. Braun $\mathrm{T}[8]$ mentioned that maternal symptoms associated with mirror syndrome disappeared shortly after treatment of fetal condition or delivery (mean 8.9 days). Sometimes delivery of the baby is difficult due to massive fetal ascites causing obstruction. Delivery is possible in these cases only after aspiration of ascetic fluid [12]. When the specific cause of fetal hydrops can be identified and corrected by in utero treatment, reversion of Ballantyne syndrome can occur [13]. Fetal treatment by intrauterine transfusion for hydrops and anemia caused by parvovirus infection and Diamond-Blackfan anemia led to the disappearance of the Mirror syndrome [14]. Placement of a peritoneal-amniotic shunt resolved the fetal hydrops and maternal mirror syndrome [15]. In utero treatment of hydropic fetus can result in disappearance of mirror syndrome. When the specific cause of fetal hydrops cannot be identified and corrected, immediate delivery is necessary in order to avoid fetal death and maternal complications. The genesis of this syndrome remains unknown and elusive though many postulations have been made like elevated serum hCG levels [16]. Placental hypoxia [17]. High levels of anti-angiogenic factor [18]. Many times it is not possible to find the cause of fetal hydrops even after detailed investigations.

\section{References}

1. O'Driscoll DT (1956) A fluid retention syndrome associated with severe isoimmunisation to the Rhesus factor. J Obstet Gynaecol Br Emp 63: 372374.

2. Reiss HE (1999) Historical insights: John William Ballantyne 18611923. Hum Reprod Update 5(4): 386-389.

3. Vidaeff AC, Pschirrer ER, Mastrobattista JM, Gilstrap LC, Ramin SM (2002) Mirror syndrome: a case report. Journal of Reproductive Medicine for the Obstetrician and Gynecologist 47(9): 770-74.

4. Touhami O, Chantraine F, Delbecque K, Bourcy E, Nisolle M (2013) Mirror syndrome: a case report in fetal medicine. Rev Med Liege 68(9): 440-443.

5. Carbillon L, Oury JF, Guerin JM, Azancot A, Blot P (1997) Clinical biological features of Ballantyne syndrome and the role of placental hydrops. Obstet Gynaecol Surv 52: 310-343.

6. Kumar B, Nazaretian SP, Ryan AJ, Simpson I (2007) Mirror syndrome: a rare entity. Pathology 39: 373-375.

7. Kaiser IH (1971) Ballantyne and triple edema. Am J Obstet Gynecol 110: 115-120. 
8. Braun T, Brauer M, Fuchs I, Czernik C (2010) Dudenhausen JW, Henrich W, Sarioglu N. Mirror Syndrome: A Systemic Review of Fetal Associated Conditions, Maternal Presentation and Perinatal outcome. Fetal Diagn Ther 27(4): 191-203

9. Takahashi H, Matsubara S, Kuwata T, Ohkuchi A, Mukoda Y, et al (2014) Maternal manifestation of Ballantyne's syndrome occurring concomitantly with the development of fetal congenital mesoblastic nephroma.J Obstet Gynaecol Res 40(4): 1114-1147.

10. Emmanuel N, Kontomanolis, M Lambropoulou, N Tsagias, N. Koutlaki, et al. (2014) The riddle of Ballantyne's syndrome in the aspect of hydrops fetalis. The Journal of Maternal-Fetal \& Neonatal Medicine 27(11): 11721173

11. Kate E, Oliver, Kimberly W, Hickey, Scott M, Petersen (2012) Spontaneous Resolution of Mirror Syndrome following Demise of Hydropic Twin Case Reports in Obstetrics and Gynecology.

12. Banner S, Crossan D (2013) Mirror Syndrome in Pregnancy: Two Patients, One Disease. Journal of Obstetric. Gynecologic \& Neonatal Nursing 42: 97-98.

13. Lobato G, Nakamura-Pereira M (2008) Reversion of the Ballantyne syndrome despite fetal hydrops persistence. Fetal Diagn Ther 24: 474477.

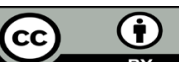

This work is licensed under Creative

Commons Attribution 4.0 License

Submission Link: http://biomedres.us/submit-manuscript.php
14. Valsky DV, Daum H, Yagel S (2007) Reversal of mirror syndrome after prenatal treatment of Dia-mond-Blackfan anemia. Prenat Diagn 27: 1161-1164.

15. Livingston JC, Malik KM, Crombleholme TM, Lim FY, Sibai BM (2007) Mirror syndrome: a novel approach to therapy with fetal peritonealamniotic shunt. Obstet Gynecol 110: 540-443.

16. Hirata G, Aloki S, Sakamaki K, Takahashi T, Hirahara F, et al. (2016) Clinical characteristics of mirror syndrome: a comparison of 10 cases of mirror syndrome with non-mirror syndrome fetal hydrops cases. The Journal of Maternal-Fetal \& Neonatal Medicine 29(16): 2630-34.

17. Gherman RB, Incerpi MH, Wing DA, Goodwin TM (1998) Ballantyne syndrome: Is placental ischemia the etiology? Journal of Maternal Fetal Medicine 7: 227-9.

18. J Espinoza, R Romero, JK Nien (2006) A role of the anti-angiogenic factor sVEGFR-1 in the "mirror syndrome" (Ballantyne's syndrome), Journal of Maternal-Fetal and Neonatal Medicine 19(10): 607-613.

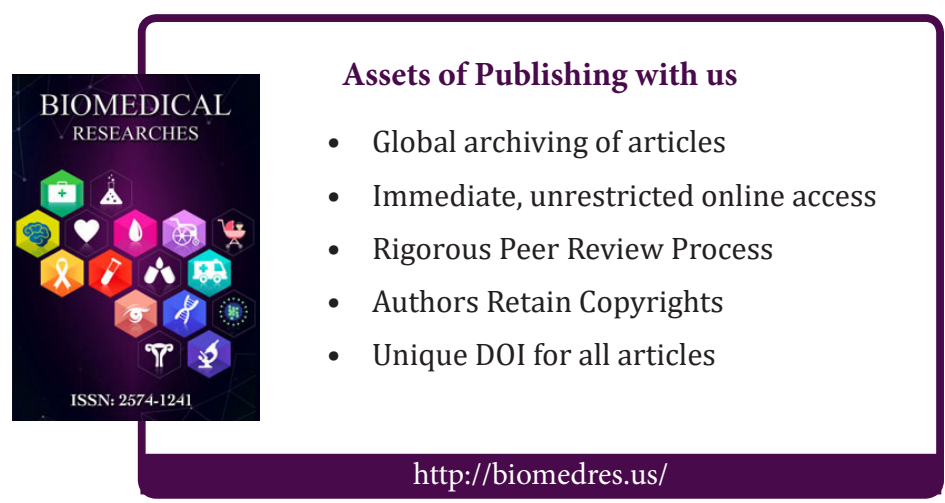

